\title{
DIGITAL TRANSFORMATION: THEORETICAL BACKGROUNDS OF DIGITAL CHANGE
}

\author{
Kamila Tratkowska \\ Wroclaw University of Economics and Business, Wroclaw, Poland \\ e-mail: kamila.jurgielewicz@ue.wroc.pl \\ ORCID: 0000-0003-2425-7890 \\ (C) 2019 Kamila Tratkowska \\ This is an open access article distributed under the Creative Commons Attribution-NonCommercial-NoDerivs license \\ (http://creativecommons.org/licenses/by-nc-nd/3.0/) \\ DOI: $10.15611 / \mathrm{ms} .2019 .4 .05$ \\ JEL Classification: M, O
}

\begin{abstract}
The purpose of this paper is a review of the existing definitions of digital transformation (abbrev. DT) and to structure its implications for new business models and implementation activities. This article was inspired by literature review whose main aim was to provide insight into the understanding of the theoretical background of digital transformation by means of the digitization and current megatrends in the VUCA world. The author gives examples, completes the literature research and shows the theoretical aspects of concepts, as well briefly analyzes the trends concerning DT. The article starts from definitions of DT, through digital readiness, to efficiency in the DT area. The main findings are that the approach for the structured digitization of business models is expanding, several excellence models have been developed over the past few years, and the implementation model for DT becomes a widely known concept. The author offers a clear definition, which corresponds to phases for DT of business models using a Digital Capability Maturity Models overview. Moreover, this paper is the author's declaration of further DT's research in its practical dimension.
\end{abstract}

Keywords: digital transformation, digitization, VUCA, Digital Maturity Model.

\section{Introduction}

Countless articles are being published highlighting Volatility, Uncertainty, Complexity and Ambiguity (abbrev. VUCA), which the world has become during the past few years. The notion of VUCA is now a trendy management concept, giving the opportunity to broadly interpret the meaning of a turbulent environment [Bennett, Lemoine 2014]. The author briefly introduces environmental changes in the numerous dimensions conditioned by VUCA and makes an attempt to structure the aspects of change driven by technology in the literature review. In the paper the fluctuating character of the present reality is described. According to the carried out review, the majority of alterations concern digital transformation, accelerated by current megatrends and their implications on business models.

The changes have an impact on society and distinct segments of industries, from manufacturing,
IT, healthcare and medical services, pharmacy, retailing up to agriculture. Therefore, VUCA indicates numerous explanations which are driven by current megatrends, such as climate change, environmental, social and economic responsibility, but also worldwide information access and globalization 2.0. Dealing within these emerging trends is a prerequisite to ensure business continuity leading to sustainable growth in new business strategy building. The acronym stands for four dimensional challenges: $\mathrm{V}$ for Volatility aims for dynamic change and speed of transformation in the world, $\mathrm{U}$ corresponds to Uncertainty highlighting the unpredictable character of the environment. Vast amounts of information stopped merely formulating good predictions and help in its analysis. Businesses are being overwhelmed by how fast information changes appear. These lead to the next abbreviation which is $\mathrm{C}$ for Complexity i.e. the numerous factors, variety of information and the complicated relationships between them. 
Complexity impacts on the environment analysis and rational conclusions. It demands thinking non-linearly and perceiving threats and opportunities as interactive, and expects a collaborative approach and stops seeking permanent solutions. The final letter A - is for Ambiguity meaning the lack of clarity when interpreting events. The high speed of information' collection, its incompleteness and fuzziness lead to vague understandings of reality [Warren, Nanus 1985]. Due to the above, the VUCA concept demands distinct types of responses from today's leaders to ride the transformation.

\section{Theoretical background}

\subsection{Brief history of Digital Transformation}

The computerization of the processes has been introduced since the early 1990s. After almost 30 years mobility, cloud computing, the Internet of Things (IoT), augmented reality, social media and decentralized public ledgers of transactions like blockchain are driving enterprises to new digital customer engagement and IT enabled processes. From the mid-2000s until today, smart devices and social platforms have been strongly influencing B2C communication methods and opening new communication channels with customers. Digital communication encouraged high expectations regarding multi-channel availability and revolutionized the Customer Service Experience within the "Customer in the Center" and real time communication approach. Within the rise of new technologies, all industries are conducting various initiatives to discover and exploit technological benefits. This engages transformations of business operating models, and also affects product portfolio. Processes and organizational structures are also to be reengineered in a way to govern the complex evolvement. The implementation of a new digital-based business model requires wide a range of capabilities to be developed, starting with the influence on people's mindset and organizational culture and the ability to change [Zinder, Yunatova 2016]. All these elements are bound together into a phenomenon called digital transformation, seemingly posing an overall readiness for change [Mugge, Gudergan 2017] and still being a challenge for entrepreneurs.

\subsection{Digital Transformation definition}

The author follows a literature review based on definitions to ensure the reader's holistic vision of DT as a prevalent term. The literature review was chosen from the proceedings of best known conferences dedicated to DT, and a study of the citation index of the authors. Moreover, the author aims to build a well-rounded understanding of the notion of Digital Transformation. The literature review of the state-of-the-art DT, brought many distinct concepts of the considered phenomenon [Kokkinakos, Markaki, Koussouris 2016]. For the purposes of this article, the author proceeded with a review of over 100 articles on digital transformation and provided an overview of definitions from the most prominent publications in Table 1.

As the above research of definitions implies, there exist different conceptualizations for Digital Transformation, which allow to categorize the DT phenomenon according to three aspects:

1. Organizational - whereas organizational processes and their idea, value creation, business models and extended supply chain are concerned as the main aims of change brought by the DT. In the set of the given definitions, the author highlights the variety of organizational aspects improved or just changed. As given by BWMi, business is driven by collected information, which is analyzed and translated into actions. The main aspect of the organizational changes is the improvement and change of the existing processes and making them smart.

2. Technological - which stands for introducing novelties in technologies and innovations, which use and enable major improvements in quality, efficiency and revenue. The technological aspects of implemented digitization, as stated by A. Martin, is that automation already performed and this is strongly influencing business, the public sector and life of society. Robotic Process Automation (RPA) is progressing. The main trend of the automation is the remote management of the infrastructure, which gives the ability of consistent investigation and predictive detection and solving of problems. The latest observations of RPA implementations are firstly resulting in standardized processes, service desk operations and monitoring networking devices - all due to scalability from human resources to handle short-term demand. As RPA brings more tech-advanced solutions to businesses around the world, operating models that adopt automation, whether by cost centre or offshored, improve service and/or product quality and bring savings in operating time.

3. Social-resulting in networking, communication channels, customer models of demand, and creating new experience and mindset among customers. The source of data derived from mass media, apps and devices used every day, provide unlimited information with which the use of technology might improve and strongly influence on daily life. The way society 
Table 1. Definitions on Digital Transformation

\begin{tabular}{|c|c|}
\hline Author(s) & Definition \\
\hline $\begin{array}{l}\text { G. Westerman, A. McAfee } \\
\text { et al. [2011] }\end{array}$ & $\begin{array}{l}\text { "(...) the use of technology to radically improve the performance or reach of enterprises is becoming } \\
\text { a hot topic for companies across the globe. Executives in all industries are using digital advances such } \\
\text { as analytics, mobility, social media, and smart embedded devices and improving their use of traditional } \\
\text { technologies such as ERP to change customer relationships, internal processes and value propositions } \\
(\ldots) \text { " }\end{array}$ \\
\hline M. Fitzgerald et al. [2013] & $\begin{array}{l}\text { "(...) use of new digital technologies, such as social media, mobile, analytics or embedded devices, in } \\
\text { order to enable major business improvements like enhancing customer experience, streamlining } \\
\text { operations or creating new business models (...)" }\end{array}$ \\
\hline $\begin{array}{l}\text { M. McDonald, } \\
\text { A. Roswell-Jones [2012] }\end{array}$ & $\begin{array}{l}\text { "(...) as such, the Digital Transformation goes beyond merely digitizing resources and results in value } \\
\text { and revenues being created from digital assets }(\ldots) \text { " }\end{array}$ \\
\hline E. Stolterman, A. Fors [2004] & $\begin{array}{l}\text { "(...) digital transformation is the changes that digital technology causes or influences in all aspects } \\
\text { of human life (...)" }\end{array}$ \\
\hline BMWi [2015] & $\begin{array}{l}\text { "(...) stands for the complete networking of all sectors of the economy and society, as well as the ability } \\
\text { to collect relevant information, and to analyze and translate that information into actions. The changes } \\
\text { bring advantages and opportunities, but they create completely new challenges (...)" }\end{array}$ \\
\hline A. Martin [2008] & $\begin{array}{l}\text { "(...) now commonly interpreted as such usage of Information and Communication Technology, when } \\
\text { not trivial automation is performed, but fundamentally new capabilities are created in business, public } \\
\text { government, and in people's and society life (...)" }\end{array}$ \\
\hline D. Mazzone [2014] & $\begin{array}{l}\text { "(...) is the deliberate and ongoing digital evolution of a company, business model, idea process, or } \\
\text { methodology, both strategically and tactically (...)" }\end{array}$ \\
\hline D. Bowersox et al. [2005] & $\begin{array}{l}\text { "(...) process of reinventing a business to digitize operations and formulate extended supply chain } \\
\text { relationships. The DBT leadership challenge is about reenergizing businesses that may already be } \\
\text { successful to capture the full potential of information technology across the total supply chain (...)". }\end{array}$ \\
\hline
\end{tabular}

Source: own elaboration.

evaluates demands is illustrated by major changes in customer experience.

To complete the definitions of Digital Transformation, the author concludes with a qualitative review of DT in the literature study based on over 100 articles.

Thus Digital Transformation is defined, and there are also examined the most relevant categories, going through the most used research areas and ISI cited keywords, as follows in Table 2.

As presented in Table 2, following the literature study, the author found important connections of Digital Transformation to Industry 4.0 concepts. The high-tech and mindset revolution in manufacturing relies on Cyber Physical System (CPS) and Business Architecture changes. CPS has provided the foundation to develop advanced industrial systems and applications by integrating functionalities through the Internet of Things (IoT) and Web of Things (WoB), as a means of enabling connectivity between physical objects with computing and infrastructure. Such end-to-end digitization brings new value by creating an ecosystem engaging all value chain partners (Lee, Lee, Chou, 2017). Networking and driving change might become critical in IT-oriented process management and in introducing a new business operating model, and speeding up the
Table 2. Research areas of DT in literature

\begin{tabular}{|c|l|}
\hline $\begin{array}{c}\text { Descending } \\
\text { frequency of use }\end{array}$ & \multicolumn{1}{c|}{\begin{tabular}{c}
\multicolumn{1}{c|}{ ISI cited keyword and research } \\
areas due to DT
\end{tabular}} \\
\hline 1 & $\begin{array}{l}\text { Information Systems and Cyber Physical } \\
\text { Systems, } \\
\text { Industry 4.0, } \\
\text { IT/IS integration }\end{array}$ \\
\hline 2 & $\begin{array}{l}\text { Business economics, } \\
\text { Digital business enterprise architecture, } \\
\text { Development of new business models }\end{array}$ \\
\hline 3 & $\begin{array}{l}\text { Education Educational technology, } \\
\text { Training/Education to add new skills }\end{array}$ \\
\hline 4 & $\begin{array}{l}\text { Management science } \\
\text { Management Process and operations } \\
\text { management }\end{array}$ \\
\hline 5 & $\begin{array}{l}\text { Government Public sector transformation } \\
\text { ramifications to other sectors, } \\
\text { Other subjects (Digital Maturity Model, } \\
\text { Digital Readiness etc.). }\end{array}$ \\
\hline
\end{tabular}

Source: own elaboration.

process cycles. This concept corresponds to Business Process Reengineering (BPR) and a standardized working place due to achieving the remotely controllable processes in virtual reality. As in the beginning of 1990s when the BPR gained fame, 
the DT researchers found similarities between BPR and DT. Hence, the authors ascertain that both DT and BPR are to reengineer business related processes in pursuance of cost reduction and widely understood process improvement.

The second important research area for Digital Transformation is business economics, digital business enterprise architecture and a new business models development. This is an indispensable success factor for any company, and for years the critical point for many businesses. As with any IT-enabled change, it is not enough to bring the solution or tool to the organization; transformation is based on structured processes and decision model changes. Due to the achieved success in such complex change management, the third of the research areas presented in the table is considered, i.e. training and education to obtain new skills and develop competences. Referring to Digital Transformation, employees or users of change must be trained in the driven process change. This requires new communication skills and acquiring new competences to enhance the way of working. The above aspect will be developed in a further part of the article referring to the phases of implementation of DT.

The fourth of the researched areas and ISI cited words is management science and management process and operating process. These research areas refer to improving aspects of driving the digital change. Instead of focusing on rule-based processes as business process reengineering did, the main objectives of Digital Transformation are based on data, which is the DNA of the transformation of old management and decision-making systems. Enhanced data-oriented approach gives the opportunity to gain new knowledge and in turn reimagine business models and operations.

The last, and fifth research area diagnosed in the literature review is governmental digitalization as one of the most promising social themes, which is planned for being developed in the future. The megatrends mentioned in the very beginning of the article, are force growing interest in international security, administration system and the healthcare sector, as there has been a significant research on the increasing digitalization of the mentioned areas in Europe, the US and Asia. There are several other issues concerning the phenomenon of DT in literature. The emerging trend in publications is structuring the approach of DT implementation. There was a recognizable significance of the existing maturity models in Digital Transformation developed primarily by practitioners in the biggest consulting agencies like EY, Deloitte, KMPG, and IDC. The academic community has not expressed a mutual consent on maturity model for Digital Transformation yet, but this offers a great research area and capability maturity models application.

\subsection{Towards excellence - Digital Transformation maturity models}

The business essentials for digital-based transformations is the high-concentration on improving or creating new values for the organization and value add chain overall, or for its products, services and cost efficiency. The way to achieve excellence and being successful in driving digital change is still unknown. However, the formula for structured implementation is still not found, while interesting knowledge sharing and networking initiatives across sectors are being observed. Their main aims are to share best practices among DT involved companies to identify the characteristics of organizations that enable business transformation and success in the digital age. One of the representatives of such concept exchanges is CIONET - the community of IT management executives and digital leaders, which serves for experience and inspirations exchange, sharing ideas, new resources and building cooperation. Such lessons learned are initiated by business leaders, who compete but also cooperate on building new value and actively foreseeing customer predispositions and demand. The community develops an Excellence Model of Digital Transformation through cyclical analysis based on successful implementations. As the model development proceeds, a collection of good practices enables establishing the success factors and principles to benefit implementations of the enterprise digital transformation [Bełz, Górczyński, Płoszajski 2018].

The Digital Excellence Model consists in areas of the assessment in the range of competences, structure, market, services, products, systems, and processes, which together brought the essence of the Digital transformation. The Digital Excellence model is under development and its high granularity might be helpful to formulate the best practice guidance for future change drivers.

Meanwhile, current megatrends call for businesses to become digital. Yet, many enterprises are about to embark on the complex digital transformation processes and encompass all the aspects of their business to redefine the way they operate. Deloitte's consulting agency in partnership with the TM Forum, over the recent years have developed a digital maturity assessment model, based on the data and their customers engagement. As the research suggests, Digital Maturity Model (DMM) consists of five assessment areas: 
1. Customer - where it concentrates on assessing customer engagement, customer experience, insights and behavior, and customer trust and perception.

2. Strategy - in this dimension, the brand management, ecosystem management, finance and investment, market and customer are taken into consideration.

Moreover, the assessment covers portfolio, ideation and innovation sphere, but also strategic and stakeholder's management.

3. Technology - under assessment of this section are applications, IoT structure, Data and Analytics, Delivery Governance, Network, Security, Technology Architecture.

4. Operations - this area covers Agile Change Management practices, Automated Resources Management, Integrated Services Management, Real-time, insights and analytics, Smart and Adaptive Process Management, Standards and Governance Automation.

5. Organization and culture - last but not least, dimension in DMM, assess Culture, Leadership and Governance, Organizational Design and Talent Management, Workforce Enablement.

DMM takes a snapshot of the as-is digital capability of the enterprise at the outset. The model is supposed to support the digital change leaders to assess the vague dimensions of the change and build a breakdown structure or roadmap to reach the desired outcome simultaneously across the business. The main aim of the model is to identify the gaps in each phase of digital transformation and bring guidance on the change process. To ensure efficiency, the model is more likely validated, in three steps. The first assesses the current state of digital maturity and identifies opportunities to define the change plan. The second step is about reviewing and prioritizing capabilities to enhance business objectives. In this stage the actions taken on the roadmap are assessed. The last measure is evaluating the process improvement and effectiveness of the initiatives to digital maturity.

The other model of the assessment, called "Digital Readiness" (EY DRA website) is suggested by EY and focuses on seven areas:

1) strategy, innovation \& growth,

2) customer experience,

3) supply chain \& operations,

4) technology,

5) risk \& cyber security,

6) finance, legal \& tax,

7) people \& organization.

The outcome of the Digital Readiness assessment is supposed to achieve knowledge about digital strengths, weaknesses and gaps. The method is the benchmark depending on the organization size, sector and business location. The "Digital Readiness" benchmark might be provided in the same sector and against digital leaders in other sectors whose tactics might be emulated.

Comparing these two models, both aiming at strategy and roadmap building to drive the change. EY's model is more granular due to the number of the assessed organizations throughout the years. The high number of analyzed companies seems a promising formula for further development in academic research.

\section{Concluding remarks}

Although Digital Transformation is a popular concept among managers and practitioners, this term tends to be forgotten and unused in the academic literature, and thus the theoretical background and conducted literature review was raised in this article. Through ISI search, it was proved to have a very common understanding of both terms, "Digital Transformation" and "Digitalization". Many of the publications may propose to readers to consider these terms as trendy managerial slogans for IT-enabled changes within new version. However, due to the scale and importance on the operating models and business strategy, this is crucial for the further development of a digital strategy roadmap well suited to the company's needs. The phenomenon of DT is not considered as only a high-tech implementation, but as a rational set of at least three elements and the common point of all the characteristics presented in this article. The given definitions and maturity models mentioned in this paper, have three common points which are technology, organization and people. These elements are a must in building digital strategy, formulating needs and identifying gaps to be filled or recreated when embarking on the journey called digital transformation. This theoretical background and literature study is the first step for the author in building the basis of digital transformation characteristics and the basis for further research in the field of digital excellence models and its practical aspects.

\section{Bibliography}

Bełz G., Górczyński B., Płoszajski P., 2018, Digital Excellence Model, https://www.digitalexcellence.pl/model (link used 09.2019).

Bennett N., Lemoine G.J., 2014, What VUCA really means for you, Harvard Business Review, January-February.

BMWi, 2015, Industrie 4.0 und Digitale Wirtschaft-Impulse für Wachstum, Beschäftigung und Innovation, Bundes Ministerium für Wirtschaft und Energie, Berlin.

Bowersox D., Closs D., Drayer R., 2005, The digital transformation: Technology and beyond, Supply Chain Management Review, 9(1), pp. 22-29. 
Deloitte, Website, https://www2.deloitte.com/content/dam/Deloitte/global/Documents/Technology-Media-Telecommunications/deloitte-digital-maturity-model.pdf (link used 09.2019).

EY DRA website, https://digitalreadiness.ey.com/ (link used 09.2019)

Fitzgerald M., Kruschwitz N., Bonnet D., Welch M., 2013, Embracing Digital Technology: A New Strategic Imperative, MIT Sloan Management Review, Research Report.

Kokkinakos P., Markaki O., Koussouris S., Psarras J., 2016, Digital transformation: is public sector following the enterprise 2.0 paradigm?, [In:] Digital Transformation and Global Society, pp. 96-105, Springer International Publishing.

Lee M.X., Lee Y.C., Chou C.J., 2017, Essential implications of the digital transformation in industry 4.0, Journal of Scientific \& Industrial Research, vol. 76, pp. 465-467.

Martin A., 2008, Digital literacy and the "digital society”, Digital Literacies Concepts Policies Practices, 30, pp. 151-176.

Mazzone D., 2014, Digital or Death: Digital Transformation The Only Choice for Business to Survive Smash and Conquer (1st ed.), Smashbox Consulting Inc.
McDonald M., Roswell-Jones A., 2012, The Digital Edge: Exploiting Information \& Technology for Business Advantage, Gartner Inc.

Mugge P., Gudergan G., 2017, The Gap Between the Practice and Theory of Digital Transformation, Whitepaper.The $50^{\text {th }}$ Hawaiian International Conference of System Science.

Stolterman E., Fors A., 2004, Information technology and the good life, Information Systems Research, pp. 687-692.

Warren B., Nanus B., 1985, Leaders: Strategies for Taking Charge.

Westerman G., McAfee A., Bonnet D., Calmejane C., Ferraris P., 2011, Digital transformation: A roadmap for billion-dollar organizations, MIT Center for Digital Business and Capgemini Consulting, pp. 1-68.

Zinder E., Yunatova I., 2016, Synergy for digital transformation: a person's multiple roles and subject domains integration, [in:] Digital Transformation and Global Society: First International Conference, June 22-24, Springer, pp. 155-168.

\section{TRANSFORMACJA CYFROWA: TEORETYCZNE ASPEKTY ZMIAN CYFROWYCH}

Streszczenie: Celem niniejszego artykułu jest przegląd istniejących definicji transformacji cyfrowej (DT) oraz wskazanie jej wpływu na nowe modele biznesowe i związane z nimi działania wdrożeniowe. Artykuł został zainspirowany przeglądem literatury - głównym zadaniem było nakreślenie tła teoretycznego poprzez rozwinięcie pojęć, takich jak digitalizacja i megatrendy w świecie VUCA. Autorka podaje przykłady, uzupełnia badania literatury, wskazując na teoretyczne aspekty transformacji cyfrowej, a także analizuje związane z nią trendy. Artykuł rozpoczyna się od definicji transformacji, a następnie omawiane są zagadnienia gotowości cyfrowej oraz wydajności. W dokonanym przeglądzie literaturowym autorka wykazała, że ustrukturyzowane podejście do cyfryzacji w modelach biznesowych wzrasta. W ciągu ostatnich kilku lat opracowano kilka modeli doskonałości cyfrowej, a modele wdrażania transformacji zyskują na popularności. W artykule zaproponowano definicję, która formułuje fazy DT z wykorzystaniem przeglądu modeli dojrzałości możliwości cyfrowych.

Słowa kluczowe: transformacja cyfrowa, digitalizacja, VUCA, model dojrzałości cyfrowej. 